\title{
Sifat-sifat Organoleptik Nikumi Kuda dan Sapi pada Beberapa Frekuensi Pencucian (Leaching)
}

\author{
Organoleptic characteristics of horse and beef nikumi on some leaching frequency \\ Olfa Mega \\ Jurusan Peternakan Fakultas Pertanian Universitas Bengkulu \\ Jalan Raya Kandang Limun Bengkulu, Telp (0736) 21170. Pst. 219.
}

\begin{abstract}
This aim of the research was purpose to study the influence of leaching on color, texture and odor of nikumi.beef and horse. The experiment was set in randomized block factorial design with two factors, namely kind of meat (horse and beef) and leaching (0, 3, 6, 9 times). Organoleptic test is used in this study with twenty five semi trained panelis The results of this study showed that leaching frequency would decreased significantly $(\mathrm{P}<0,5)$ on odor, color and texture of horse and beef nikumi. Horse nikumi was more odor
\end{abstract}

Key words : leaching, nikumi, horse and beef, organoleptic properties.

\begin{abstract}
ABSTRAK
Penelitian bertujuan untuk mengetahui sifat-sifat organoleptik nikumi kuda dan sapi,. dengan menggunakan rancangan acak kelompok pola faktorial. Faktor pertama adalah jenis daging yaitu daging kuda dan daging sapi, faktor kedua adalah frekuensi pencucian ( 0, 3, 6 dan 9 kali). Uji yang digunakan adalah uji rating melibatkan 25 orang panelis semi terlatih meliputi penilaian terhadap warna, tekstur, bau atau aroma. Hasil penelitian menunjukkan bahwa peningkatan frekuensi leaching nyata $(\mathrm{P}<0,05)$ menurunkan aroma, warna dan tekstur nikumi kuda dan sapi. Pada leaching 3 kali aroma nikumi kuda lebih amis dibanding nikumi sapi tetapi relatif sama pada leaching 6 kali dan 9 kali. Warna nikumi kuda lebih merah dari nikumi sapi sampai leaching 9 kali, sedangkan tekstur nikumi kuda lebih kasar dari nikumi sapi kecuali pada leaching 3 kali teksturnya relatif sama.
\end{abstract}

Kata kunci : leaching, nikumi kuda dan sapi, organoleptik

\section{PENDAHULUAN}

Ternak kuda mempunyai potensi yang cukup besar sebagai penghasil daging. Populasi ternak kuda di Indonesia mencapai 430.423 ekor, populasi terbesar berturut-turut berada di propinsi Sulawesi Selatan, Nusa Tenggara Timur, Nusa Tenggara Barat, Jawa Timur dan Sulawesi Utara. Produksi daging kuda rata-rata 934 ton per tahun yang berasal dari 7268 ekor pemotongan (Ditjenak, 2001). Namun demikian konsumsi daging kuda khususnya di Indonesia belum sepopuler daging sapi, kambing, domba dan ternak unggas, hal ini dipengaruhi oleh faktor budaya, ketersediaan, rasa dan aromanya yang kurang enak. Untuk itu perlu dilakukan upaya untuk menghilangkan bau atau aroma yang tidak disukai supaya daging kuda diterima secara luas.

Leaching adalah proses pencucian daging ikan yang diterapkan pada teknologi pembuatan surimi. Surimi adalah istilah dalam bahasa Jepang untuk nama suatu produk yang berasal dari daging ikan (nikumi untuk produk yang berasal dari daging ternak) yang sudah dipisahkan dari tulang-tulangnya, digiling secara mekanis dan dicuci beberapa kali dengan air dingin untuk memisahkan komponen yang larut air. Surimi merupakan bahan antara untuk diolah menjadi produkproduk lanjutan yang membutuhkan sifat elastisitas daging ikan seperti kamaboko, bakso ikan, sosis ikan dan lain-lain. Tujuan dari leaching diantaranya adalah untuk menghilangkan bau dan warna pada daging. Leaching pada daging ikan biasa dilakukan 
sebanyak 3 atau 4 kali. Daging kuda merupakan jenis daging merah dan mempunyai warna yang lebih merah dan tingkat keamisan yang lebih tinggi dari daging ikan, untuk itu frekuensi pencucian dilakukan lebih dari frekuensi pencucian pada daging ikan. Penelitian ini bertujuan untuk mengetahui pengaruh leaching pada daging kuda dan sapi terhadap sifat-sifat organoleptik nikumi kuda dan sapi.

\section{MATERI DAN METODE}

Daging sapi dan daging kuda yang digunakan berasal dari ternak yang sudah tua (umur kuda diatas 8 tahun dan sapi diatas 4 tahun). Pengambilan daging kedua ternak ini dilakukan setiap 7 hari selama 3 kali (3 ulangan atau kelompok) dari ternak yang berbeda. Daging bagian paha (Bicep femoris) dari kedua ternak ini dipisahkan dari lemak dan jaringan ikat. Daging digiling dengan grinder plate mincer, untuk tiap kelompok digunakan sebanyak 500g daging. Air dengan suhu $\pm 5^{\circ} \mathrm{C}$ ditambahkan dengan perbandingan 3:1 (v/w) air:daging. Leaching dilakukan sesuai dengan perlakuan, yaitu : P0 (tanpa leaching), P1 (3 kali leaching), P2 (6 kali leaching) dan P3 (9 kali leaching), pada leaching terakhir menggunakan air garam dengan konsentrasi 0,3 persen. Buang air dalam daging dengan cara penyaringan dengan kain katun atau saringan nilon dengan ukuran mesh 1,2 - 3,2 mm (Tan et al, 1988) dan pengepresan dengan alat pengepres. Daging yang sudah dicuci (raw nikumi) ditambahkan antidenaturan (4\% sukrosa, $4 \%$ sorbitol , 0,2 \% polifosfat) dan campur sampai homogen dengan food processor. Nikumi dikemas dengan plastik polietilen dan simpan dalam freezer yang bersuhu $-20^{\circ} \mathrm{C}$.

Pengujian organoleptik menggunakan uji rating terhadap warna, tekstur dan bau atau aroma nikumi dengan skala 1 - 6 Pengujian ini melibatkan 25 orang panelis semi terlatih (Soekarto dan Hubies, 1992)

Table 1. Transformasi nilai numerik pada data uji rating

\begin{tabular}{lllc}
\hline Aroma & Warna & Tekstur & Nilai Numerik \\
\hline Amat sangat amis & Merah gelap & amat sangat halus & 1 \\
Sangat amis & Sangat merah & sangat halus & 2 \\
Amis & Merah & halus & 3 \\
Agak amis & Agak merah & agak halus & 4 \\
Sedikit amis & Sedikit merah & sedikit kasar & 5 \\
Tidak amis & Tidak merah (Putih) & tidak halus (kasar) & 6 \\
\hline
\end{tabular}

Percobaan ini menggunakan Rancangan Acak Kelompok dengan pola faktorial $2 \times 5$ dengan tiga kelompok, waktu pengambilan sampel sebagai kelompok. Faktor pertama adalah jenis daging yang terdiri dari daging sapi dan daging kuda, dan faktor kedua adalah jumlah frekuensi leaching yaitu 0, 3, 6 dan 9 kali. Data yang diperoleh diolah dengan metode Kruskal-Wallis dengan Uji Lanjut
Multiple Comparison Means Ranks Test (Gibbons, 1975).

\section{HASIL DAN PEMBAHASAN}

Hasil uji organoleptik yang digunakan terhadap nikumi kuda dan sapi adalah uji rating, hasil dari uji ini disajikan dalam tabel berikut

Tabel 2. Hasil Uji Rating Nikumi Kuda dan Sapi berdasarkan modus

\begin{tabular}{|llcccc|}
\hline Peubah & Jenis Daging & \multicolumn{4}{c|}{ Frekuensi Leaching (kali) } \\
\cline { 3 - 6 } & & 0 & 3 & 6 & 9 \\
\hline Aroma & Kuda & $2^{\mathrm{e}}$ & $4^{\mathrm{de}}$ & $5^{\mathrm{bcd}}$ & $6^{\mathrm{a}}$ \\
& Sapi & $4^{\mathrm{cd}}$ & $5^{\mathrm{bc}}$ & $5^{\mathrm{ab}}$ & $6^{\mathrm{a}}$ \\
\hline Warna & Kuda & $1^{\mathrm{d}}$ & $3^{\mathrm{cd}}$ & $4^{\mathrm{bc}}$ & $5^{\mathrm{ab}}$ \\
& Sapi & $3^{\mathrm{cd}}$ & $4^{\mathrm{b}}$ & $5^{\mathrm{ab}}$ & $6^{\mathrm{a}}$ \\
\hline Tekstur & Kuda & $3^{\text {cde }}$ & $3^{\mathrm{abcd}}$ & $4^{\mathrm{ab}}$ & $5^{\mathrm{a}}$ \\
& Sapi & $2^{\mathrm{e}}$ & $3^{\mathrm{de}}$ & $3^{\mathrm{bcde}}$ & $4^{\mathrm{abc}}$ \\
\hline
\end{tabular}


Angka yang diikuti superskrip huruf besar berbeda pada baris atau kolom yang sama menunjukkan perbedaan nyata $(\mathrm{P}<0.05)$.

Aroma

Aroma daging bersama-sama dengan cita rasa membentuk flavor daging yang melibatkan indera perasa, pembau dan keduanya. Hasil analisis Kruskal Wallis menunjukkan bahwa leaching berpengaruh nyata $(\mathrm{P}<0,05)$ terhadap aroma nikumi. Aroma nikumi kuda tanpa leaching sangat amis (skor 2) dibanding dengan nikumi daging kuda yang telah mengalami proses leaching, karena leaching dapat memisahkan prekursor bau amis pada daging. Prekursor dari flavor daging adalah komponen yang larut dalam air (asam amino, peptida, karbohidrat, nukleotida, tiamin, dll ) dan lipid (Shahidi, 1997), ditambahkan oleh Lanier dan Lee (1992), tujuan leaching adalah pemisahan daging dari bahan yang larut air, lemak dan darah (pigmen), untuk memperbaiki flavor dan warna serta meningkatkan kekuatan pembentukan gel. Aroma daging kuda tanpa leaching lebih amis (skor 2) disbanding daging sapi tanpa leaching (Skor 4), kondisi ini diduga disebabkan oleh daging kuda berasal dari ternak yang lebih tua, mengingat pemanfaatan kuda sebagai tega kerja. Hikmah (2003) menyatakan semakin tua umur ternak kuda menghasilkan suatu komponen flavor yang kurang disukai. Ditambahkan oleh Ketaren (1986), bau amis daging disebabkan oleh terbentuknya trimetil-amin, dalam otot ikan atau dalam jaringan hewan terdapat dalam bentuk persenyawaan oksida yaitu trimetilamin oksida ( $\mathrm{NMe}_{3}$ ) akibat oksidasi trimetil amin oleh peroksida. Tingginya kadar zat besi (Fe) dalam daging kuda ditandai dengan tingginya jumlah myoglobin (globulin protein yang mempunyai inti Fe) (Aberle, et al, 2001) ,akan mempercepat pembentukan peroksida yang menghasilkan trimetil-amin (Ketaren, 1986)

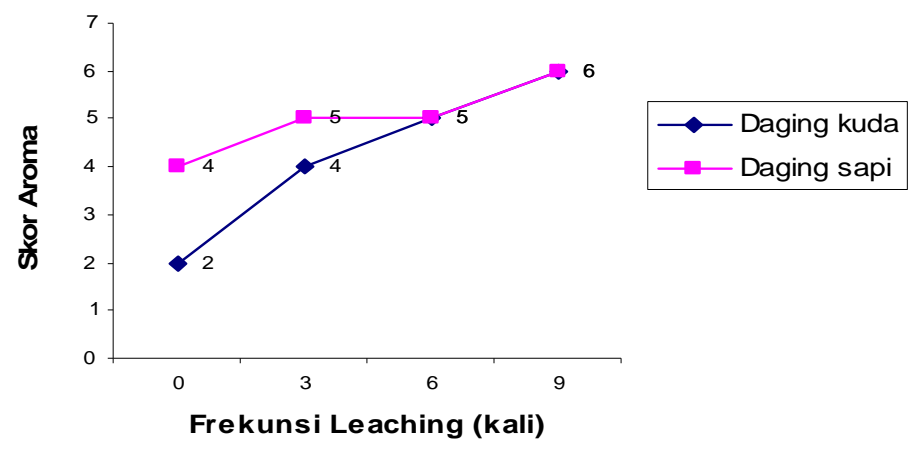

\section{Warna}

Warna daging merupakan karakteristik kualitas daging yang penting, tidak hanya bagi industri pengolahan daging tetapi juga bagi konsumen rumah tangga. sebagai konsumen persepsi paling awal pada saat akan membeli daging dan menjadi pertimbangan utama adalah warna. Konsumen mengaitkan antara warna dengan kesegaran daging, warna daging segar adalah merah cerah (bright red) dan penyimpangan dari warna ini menjadikan daging tersebut tidak diterima (Abustam, 2003). Penentu utama warna daging adalah pigmen daging yang terdiri dari dua macam protein, yaitu hemoglobin dan myoglobin. Myoglobin menempati $80-90 \%$ dari seluruh pigmen.

Hasil penelitian menunjukkan bahwa leaching berpengaruh nyata $(\mathrm{P}<0,5)$ terhadap warna nikumi yang dihasilkan. Warna daging kuda tanpa leaching lebih merah dari daging sapi, hal ini dipengaruhi beberapa faktor, antara lain kandungan myoglobin yang lebih tinggi, umur ternak kuda yang dipotong relatif tua dan aktivitas fisik ternak kuda sebagai hewan pekerja. Hal ini sesuai dengan hasil 
penelitian Hikmah (2003) yang menyatakan umur berpengaruh terhadap warna daging, kuda umur 10 tahun menghasilkan intensitas warna daging yang lebih gelap dibanding dengan kuda yang berumur 5 tahun. Daging dari ternak yang dipekerjakan lebih merah dari daging ternak yang kurang aktif karena terjadinya peningkatan kandungan myoglobin (Lawrie, 1995).

Perlakuan leaching menyebabkan pigmen warna daging dan darah ikut larut bersama air cucian sehingga warna daging setelah leaching menjadi pucat. Semakin banyak frekuensi leaching warna daging semakin pucat, pada frekuensi leaching 9 kali warna nikumi kuda terlihat lebih merah (skor 5) dari nikumi sapi (skor 6) karena daging kuda umumnya berwarna merah gelap (dark red) dibanding daging sapi yang berwarna merah cerah (bright red) (Aberle et al, 2001)

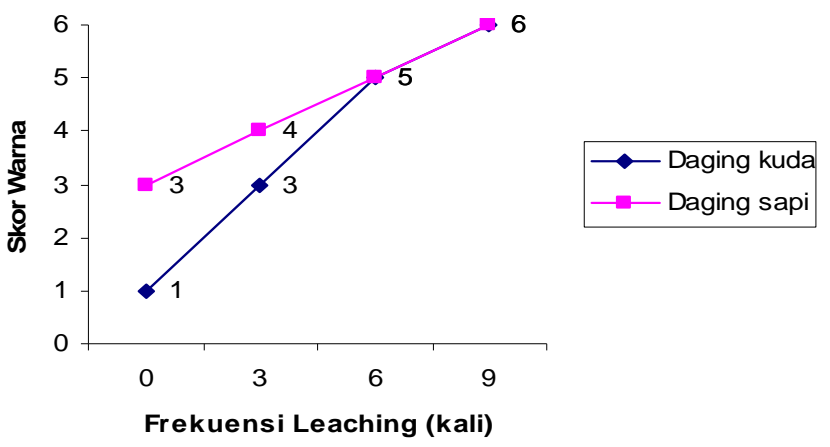

\section{Tekstur}

Tekstur merupakan karakteristik daging yang sulit diuji secara objektif, sifat ini diukur oleh konsumen secara visu

al, diraba dan dirasa. Hasil analissis Kruskal-Wallis menunjukkan tekstur nikumi dipengaruhi oleh perlakuan leaching $(\mathrm{P}<0,5)$. Respon panelis terhadap tekstur nikumi adalah dari halus (skor 2) sampai sedikit halus (skor 5).

Tekstur nikumi kuda lebih kasar dari nikumi sapi kecuali pada perlakuan 3 kali leaching, pada perlakuan ini tekstur antara nikumi kuda dan nikumi sapi sama yaitu agak halus. Hal ini didukung oleh pernyataan Aberle et al (2001) bahwa tekstur daging yang kasar dijumpai pada hewan tua. Tekstur yang kasar pada nikumi kuda diduga disebabkan umur ternak yang dipotong relatif tua. Leaching sangat nyata menurunkan tekstur nikumi kuda dan sapi, hal ini diduga karena pada proses leaching terjadi pengurangan kandungan komponen-komponen yang berhubungan dengan tekstur daging seperti lemak dan protein. 



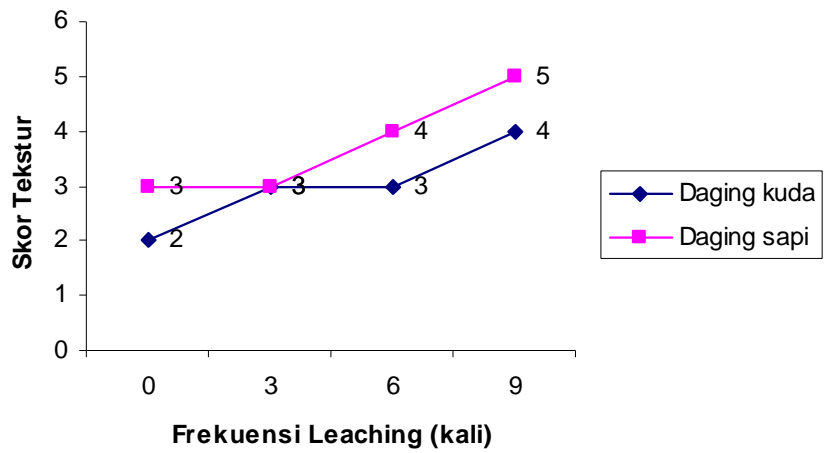

Jurnal Sain Peternakan Indonesia Vol. 2, No 1, Januari - Juni 2007 


\section{SIMPULAN}

Pada leaching 3 kali aroma nikumi kuda lebih amis dibanding nikumi sapi tetapi relatif sama pada leaching 6 kali dan 9 kali. Warna nikumi kuda lebih merah dari nikumi sapi sampai leaching 9 kali, sedangkan tekstur nikumi kuda lebih kasar dari nikumi sapi kecuali pada leaching 3 kali teksturnya relatif sama.

\section{DAFTAR PUSTAKA}

Aberle ED, Forrest JC, Gerrard DE and Mills EW. 2001. Principles of Meat Science. Fourth Ed. Kendal/Hunt Publishing Company. Amerika.

Abustam, E. 2003. Metode organoleptik dalam penilaian kualitas daging. [makalah akademis]. Fakultas Peternakan Universitas Hasanuddin, Makasar.

Babji AS and Gna SK. 1994. Change in colour, pH, WHC, protein extraction and gel strength during processing of chicken surime (ayami). Asean Food J 9(2): 63-67.

[Ditjenak] Direktorat Jenderal Peternakan Departemen Pertanian. 2001. Buku Statistik Peternakan. Jakarta.
Gibbons, J. 1975. Non Parametric Method for Quantitative Analysis. Elsevier Co, Alabama.

Hikmah. 2003. Karakteristik Fisik, kimia dan organoleptik daging kuda di Sulawesi Selatan [tesis]. Sekolah Pascasarjana Institut Pertanian Bogor, Bogor.

Ketaren, S. 1986. Pengantar Teknologi Minyak dan Lemak Pangan. UI Press, Jakarta.

Lanier TC, Lee CM. 1992. Surimi Technology. New York: Mercel Dekker.

Lawrie RA. 1991. Meat Science. Ed Ke-4. Pergamon Press. Oxford.

Park S, Brewer MS, Novakovski J, Bechtel PJ and McKeith FK. 1996. Process and Characteristics for a Surimi-Like Material Made from Beef or Pork. J Food Sci 61(2):422-427.

Shahidi, F. 1997. Flavor of Meat, Meat Products and Seafood. Blackie Academic \& Profesional, London.

Steel RGD, JH Torrie.1995. Prinsip dan Prosedur Statistik. Gramedia Pustaka Utama. Jakarta.

Suzuki T. 1981. Fish and Krill Protein Processing Tecnology. Aplied Sci Publ Ltd. London.

Tan SM, Ng MC, Fujiwara T, Kok Kuang $\mathrm{H}$ and Hasegawa H. 1988. Handbook on the Processing of Frozen Surimi and Fish Jelly Products in Southeast Asia. Singapore. Marine Fisheries Research Department-South East Asia Fisheries Development Centre.

Jurnal Sain Peternakan Indonesia Vol. 2, No 1, Januari - Juni 2007 